\title{
The effect of foreign currency borrowing and financial development on exports: a dynamic panel analysis on Asia-Pacific countries
}

\begin{abstract}
This paper examines the effect of foreign currency borrowing and financial development on exports. A balanced panel data is constructed for the selected 17 East Asian-Pacific countries, and the cointegration relationship among the variables of the export demand function is verified using Pedroni's heterogeneous panel cointegration tests. The empirical results indicate that the effect of foreign debt on exports is conditional on the magnitude of currency depreciation. The larger the depreciation of a currency, the more its exports are adversely affected by its foreign liability. This finding might be a possible explanation as to why large exchange rate depreciation during the 1997 financial crisis failed to generate the export boom. The results also show different effects of financial shocks on exports in these economies.
\end{abstract}

Keyword: Panel cointegration; Export demand function; Foreign currency borrowing; Financial development 